\title{
MIĘDZYNARODOWE SPOTKANIE „BRUSZCZEWO. BADANIA MIKROREGIONU Z TERENU WIELKOPOLSKI", ŚMIGIEL, WOJ. WIELKOPOLSKIE, 7-8 SIERPNIA 2004 R.
}

W dniach 7-8 sierpnia 2004 r. w Śmiglu (pow. Kościan, woj. wielkopolskie) odbyło się międzynarodowe spotkanie „Bruszczewo. Badania mikroregionu z terenu Wielkopolski”. Jego głównymi organizatorami były: Instytut Prahistorii Uniwersytetu im. Adama Mickiewicza w Poznaniu, Otto-Friedrich-Universität w Bambergu oraz Urząd Miasta i Gminy Śmigiel.

Spotkanie miało dwa zasadnicze cele. Pierwszym z nich było zaprezentowanie rezultatów badań wykopaliskowych na wczesnobrązowej osadzie obronnej w Bruszczewie szerszemu gronu zainteresowanych - przede wszystkim mieszkańcom Śmigla i okolic, czemu służył pierwszy dzień obrad. Składała się nań sesja popularnonaukowa, połączona ze zwiedzaniem wykopalisk. Drugim celem była dyskusja dotycząca różnych aspektów naukowych związanych z, ,projektem bruszczewskim”, czemu poświęcone było seminarium w dniu następnym.

Sesję popularnonaukową rozpoczął Burmistrz Miasta i Gminy Śmigiel J. Cieśla. Przywitał on licznie zgromadzonych gości, między innymi Prorektora Uniwersytetu im. Adama Mickiewicza w Poznaniu prof. dr. hab. B. Marciniaka, członków władz powiatu kościańskiego, miasta Kościana i Śmigla, przedstawicieli instytucji oświatowych i kulturalnych z Leszna, Kościana i Śmigla oraz lokalne media. Następnie prof. UAM dr hab. J. Czebreszuk oraz prof. dr hab. J. Müller (Otto-Friedrich-Universität w Bambergu) wygłosili referat na temat: Osada obronna z poczatku epoki brazu w Bruszczewie: znaczenie naukowe i potencjalna waga w promocji regionu. Podkreślili oni wielkie znaczenie Bruszczewa zarówno dla archeologii Europy Środkowej, jak i lokalnej społeczności, zwracając szczególną uwagę na istotne wsparcie Gminy w prowadzonych badaniach. Referat wywolał ożywioną dyskusję. Poruszane były głównie problemy dalszych perspektyw badań archeologicznych w Bruszczewie oraz możliwości ich wykorzystania w promocji regionu.

Kolejnym punktem programu było zwiedzanie stanowiska, mające na celu zaznajomienie wszystkich zainteresowanych z aktualnym stanem badań osady obronnej oraz prezentację materiałów źródłowych z sezonu 2004.

Druga część sympozjum miała charakter naukowego seminarium. Wzięło w nim udział 25 badaczy z Bambergu, Berlina, Poznania i Krakowa. Prezentowali oni swoje komunikaty w języku polskim, niemieckim i angielskim. Wygłoszono 5 komunikatów dokumentujących efekty interdyscyplinarnego programu badawczego dotyczącego stanowiska nr 5 w Bruszczewie. 


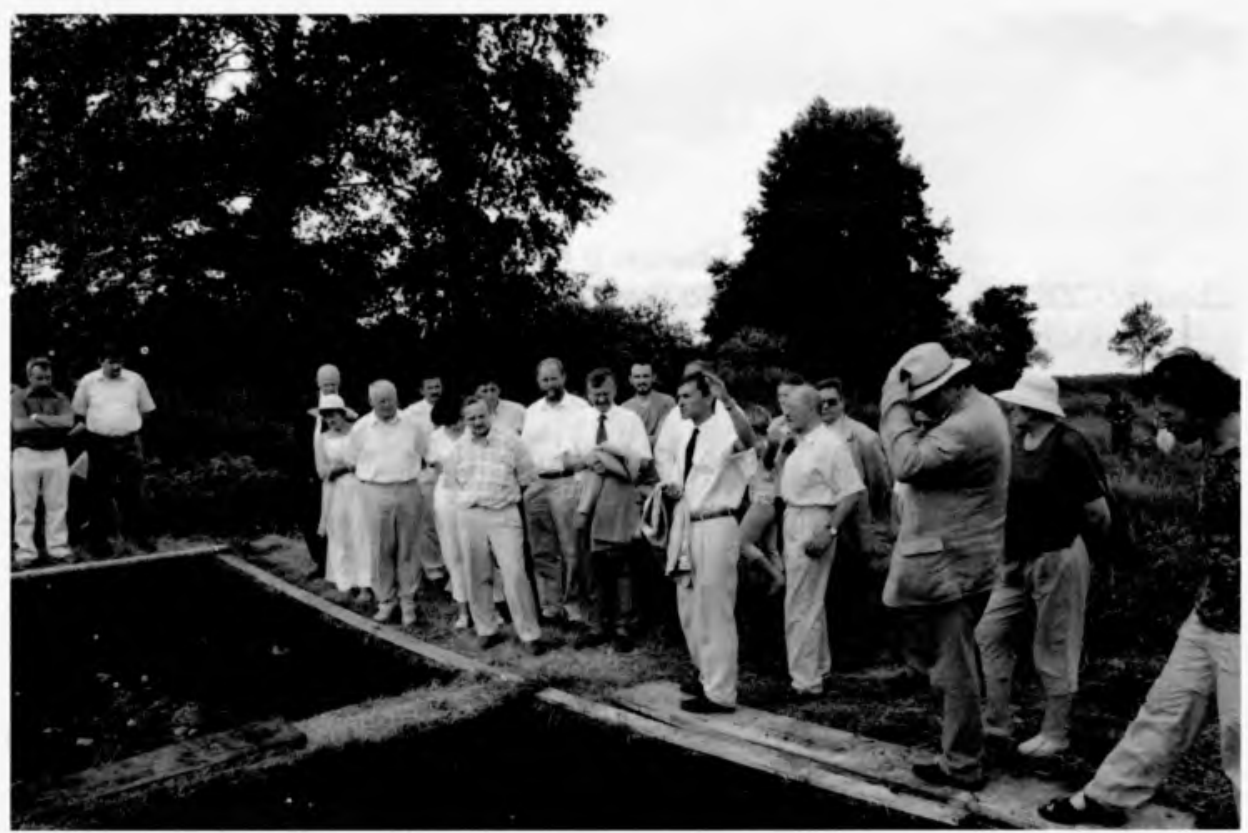

Uczestnicy spotkania podczas zwiedzania wykopalisk

Seminarium rozpoczął prof. UAM dr hab. J. Czebreszuk, witając uczestników oraz prezentując główne cechy stanowiska w Bruszczewie. Następnie przekazał on przewodnictwo obrad prof. dr. hab. S. Kadrowowi (Instytut Archeologii i Etnologii PAN w Krakowie).

Jako pierwsza swój komunikat wygłosiła dr I. Hildebrandt-Radke (Wydział Nauk Geograficznych i Geologicznych UAM), przedstawiając zarys charakterystyki geomorfologicznej otoczenia osady w Bruszczewie. Charakterystyka owa została dokonana w dwóch zakresach, a mianowicie: (a) szerszym - konwencjonalnie wyznaczonym przez koło o promieniu $10 \mathrm{~km}$ oraz (b) węższym - ograniczonym do formy geomorfologicznej, na której usytuowane jest stanowisko. Jednocześnie zaznaczyła, że tak przedstawiony zarys należy traktować jedynie jako punkt wyjścia do badań zaplanowanych na najbliższe lata, prowadzonych głównie w bezpośrednim otoczeniu osady.

W drugim wystąpieniu prof. dr hab. J. Müller (Uniwersytet w Bambergu) przedstawił aktualny stan badań części torfowej stanowiska oraz wyniki prospekcji geomagnetycznej. Stan opracowania materiałów archeologicznych ze wschodniej, torfowej części stanowiska charakteryzuje się aktualnie największym stopniem zaawansowania. Jest to też obszar, który dzięki nadzwyczaj dobrym warunkom konserwacji źródeł organicznych ma największy potencjał informacyjny, zarówno pod względem danych kulturowych, jak i przyrodniczych. Z kolei prospekcja geomagnetyczna przyniosła 
zaskakująco dokladne informacje dotyczące konstrukcji całego układu umocnień na stanowisku.

Następnie mgr J. Kneisel (Freie Uniwersität w Berlinie) w obszernym referacie zaprezentowała analizę typochronologiczną ceramiki ze strefy torfowej stanowiska. Zestawiając wyniki analizy naczyń ze stratygrafią wykopów, wydzieliła 8 horyzontów archeologicznych, dowodząc kontynuatywnego ich następstwa. Ostatecznym rezultatem dociekań było stwierdzenie, iż stratygrafia części torfowej osady w Bruszczewie potwierdza typologiczno-chronologiczne określenia funkcjonujące w literaturze, jednakże pozwala również uzyskać bardziej szczegółowy obraz zmian. Referat mgr J. Kneiseł wywołał ożywioną dyskusję, która koncentrowała się na zagadnieniu obecności czy też braku hiatusów w zaprezentowanej przez referentkę sekwencji typochronologicznej.

Mgr P. Honig (Uniwersytet w Bambergu) przedstawił rezultaty badań dotyczących wyrobów kamiennych, również ze strefy torfowej stanowiska. Stwierdził on, że kamienie, a zwłaszcza krzemienie, otoczaki, thuki, żarna i rozcieracze dostały się do strefy brzegowej na skutek karczunku pierwotnego, podmokłego lasu oraz przemieszczeń ziemi w trakcie budowy umocnien. Referent wysunął również hipotezę, iż duże nagromadzenie eratyków i fragmentów żaren na obrzeżach osady wczesnobrązowej (konkretnie nad brzegiem rzeki) może wskazywać na fakt usytuowania w tym miejscu produkcji ceramiki.

Ostatni referat wygłosil doc. dr hab. D. Makowiecki (Instytut Archeologii i Etnologii PAN w Poznaniu), który przybliżył kwestię badań archeozoologicznych szczątków kostnych z wybranych części osady. Na osadzie odkryto wielotysięczne depozyty głównie pokonsumpcyjnych kości zwierząt zarówno domowych, jak i dzikich. Już teraz jest to jeden $z$ najcenniejszych tego typu zespołów w calej wczesnobrązowej archeologii w Europie.

Na zakończenie obrad odbyła się generalna dyskusja nad najbardziej inspirującymi poznawczo zagadnieniami poruszanymi podczas poszczególnych referatów. Podejmowano w niej różnorodne zagadnienia, także dotyczące mikroregionu otaczającego Bruszczewo, relacje człowiek-środowisko na samym stanowisku, jak i w - szerszej przestrzennie - perspektywie, obejmującej dorzecze środkowej Obry.

Sympozjum bruszczewskie miało niewątpliwie charakter prekursorski. $Z$ jednej strony ukazało szerszym kręgom społeczeństwa jedno $\mathrm{z}$ najważniejszych stanowisk archeologicznych w Wielkopolsce. $Z$ drugiej zaś stało się zaczynem do pogłębiania dyskusji wśród badaczy - członków zespołu badającego osadę w Bruszczewie, do przyszłej syntezy wyników ich studiów. Spotkanie po raz pierwszy w tak pehnej formie ukazało rezultaty interdyscyplinarnych badań na stanowisku, będące efektem wielu lat pracy badaczy z licznych ośrodków europejskich. Należy podkreślić, iż w gronie specjalistów znalazły się osoby, których doświadczenie naukowe związane jest $\mathrm{z}$ odmiennymi tradycjami akademickimi i zainicjowana dyskusja była pewnego rodzaju próbą znalezienia wspólnej formuły badawczej oraz wytyczenia nowych kierunków dalszych badań. Wszyscy obecni zgodnie pokreślili, iż niezmiernie ważne jest, by rezultaty badań oraz pewnego rodzaju 
n ow e spojrzenie na wczesnobrązową osadę obronną w Bruszczewie znalazły szersze grono odbiorców we wszystkich krajach Europy. Solidną podstawą ku temu stanie się z pewnością publikacja prezentująca w sposób wyczerpujący wszystkie kwestie poruszone podczas sesji naukowej.

Agnieszka Matuszewska

Instytu Prahistorii, Uniwersytet im. Adama Mickiewicza

ul. Św. Marcin 78, 61-809 Poznań, Poland 